\title{
Towards a model of green political economy: from ecological modernisation to economic security
}

\author{
John Barry \\ Institute of Governance \\ Centre for Sustainability and Environmental Governance \\ Queen's University Belfast, BT7 1NN, UK \\ E-mail: j.barry@qub.ac.uk
}

\begin{abstract}
Perhaps the weakest aspect of the 'triple bottom line' understanding of sustainable development has been the 'economic' dimension. Much of the thinking about the appropriate 'political economy' to underpin sustainable development has been either utopian (as in some 'green' political views) or 'business as usual' approaches. This article suggests that 'ecological modernisation' is the dominant conceptualisation of 'sustainable development' within the UK, and illustrates this by looking at some key 'sustainable development' policy documents from the UK Government. While critical of the reformist 'policy telos' of ecological modernisation, supporters of more radical versions of sustainable development need to also be aware of the strategic opportunities of this policy discourse. In particular, the article suggests that the discourse of 'economic security' ought to be used as a way of articulating a radical, robust and principled understanding of sustainable development, which offers a normatively compelling and policy-relevant path to outlining a 'green political economy' to underpin sustainable development.
\end{abstract}

Keywords: green political economy; sustainable development; economic security; ecological modernisation.

Reference to this paper should be made as follows: Barry, J. (2007) 'Towards a model of green political economy: from ecological modernisation to economic security', Int. J. Green Economics, Vol. 1, Nos. 3/4, pp.446-464.

Biographical notes: Dr. John Barry is Director of the Institute of Governance, Public Policy and Social Research and Co-Director of the Centre for Sustainability and Environmental Governance at Queen's University Belfast. His areas of research include the normative aspects of environmental policy, politics and sustainable development; environmental governance; the governance of science and innovation; the link between academic knowledge and policy making; trust, legitimacy and public policy; citizenship, public policy and governance; theories and practices of reconciliation in Northern Ireland. His books include: Rethinking Green Politics (1999) - (winner of the Political Studies Association Mackenzie prize for best book published in political science); Environment and Social Theory (1999); Citizenship, Sustainability and Environmental Research (2000). 


\section{Introduction}

Economic analysis has been one of the weakest and least developed areas of broadly green/sustainable development thinking. For example, whatever analysis there is within the green political canon is largely utopian - usually based on an argument for the complete transformation of modern society and economy as the only way to deal with ecological catastrophe, an often linked to a critique of the socioeconomic failings of capitalism that echoed a broadly radical Marxist/socialist or anarchist analysis; or underdeveloped - due, in part, to the need to outline and develop other aspects of green political theory. However, this gap within green thinking has recently been filled by a number of scholars, activists, think tanks, and environmental NGOs who have outlined various models of green political economy to underpin sustainable development political aims, principles and objectives.

The aim of this article is to offer a draft of a realistic, but critical, version of green political economy to underpin the economic dimensions of radical views about sustainable development. It is written explicitly with a view to encouraging others to think through this aspect of sustainable development in a collaborative manner. Combined realism and radicalism marks this article, which starts with the point that we cannot build or seek to create a sustainable economy ab nihlo, but must begin from where we are, with the structures, institutions, modes of production, laws and regulations that we already have. Of course, this does not mean simply accepting these as immutable or set in stone; after all, some of the current institutions, principles and structures underpinning the dominant economic model are the very causes of unsustainable development. We do need to recognise, however, that we must work with (and 'through' - in the terms of the original German Green Party's slogan of 'marching through the institutions') these existing structures, as well as change and reform and in some cases, abandon them as either unnecessary or positively harmful to the creation and maintenance of a sustainable economy and society.

Equally, this article also recognises that an alternative economy and society must be based in the reality that most people (in the West) will not democratically vote for a completely different type of society and economy. That reality must also accept that a 'green economy' is one that is recognisable to most people and that indeed safeguards and guarantees not just their basic needs but also aspirations (within limits). The realistic character of the thinking behind this article accepts that consumption and materialistic lifestyles are here to stay (so long as they do not transgress any of the critical thresholds of the triple bottom line) and indeed there is little to be gained by proposing alternative economic systems, which start from a complete rejection of consumption and materialism. The appeal to realism is in part an attempt to correct the common misperception (and self-perception) of green politics and economics requiring an excessive degree of self-denial and a puritanical asceticism (Goodin, 1992, p.18; Allison, 1991, p.170-178). While rejecting the claim that green political theory calls for the complete disavowal of materialistic lifestyles, it is true that green politics does require the collective reassessment of such lifestyles, and does require a degree of shared sacrifice. It does not mean, however, that we necessarily require the complete and across-the-board rejection of materialistic lifestyles. There must be room and tolerance in a green economy for people to live 'ungreen lives' so long as they do not 'harm' others, threaten long-term ecological sustainability or create unjust levels of socioeconomic inequalities. 
Thus, realism in this context is in part another name for the acceptance of a broadly 'liberal' or 'post-liberal' (but certainly not anti-liberal) green perspective. ${ }^{1}$

At the same time, while critical of the 'abstract' and 'unrealistic' utopianism that peppers green and radical thinking in this area, I do not intend to reject utopianism. Indeed, I agree with Oscar Wilde that a map of the world that does not have utopia on it, is not worth looking at. The spirit in which this article is written is more in keeping with framing green and sustainability concerns within a 'concrete utopian' perspective (Hayward, 1995) or what the Marxist geographer Harvey (1996) calls a 'utopianism of process', to be distinguished from 'closed', blueprint-like and abstract utopian visions. Accordingly, the model of green political economy outlined here is in keeping with Lukes' (1984, p.158) suggestion that a concrete utopianism depends on the 'knowledge of a self-transforming present, not an ideal future'.

It accepts the current dominance of one particular model of green political economy - namely, 'Ecological Modernisation' (EM) - as the preferred 'political economy' underpinning contemporary state and market forms of sustainable development, and further accepts the necessity for green politics to positively engage in the debates and policies around EM from a strategic (as well as a normative) point of view. However, it is also conscious of the limits and problems with ecological modernisation, particularly in terms of its technocratic, supply-side and reformist 'business as usual' approach, and seeks to explore the potential to radicalise EM or use it as a 'jumping off' point for more radical views of greening the economy.

The article begins by outlining EM in theory and practice, specifically in relation to the British state's 'sustainable development' policy agenda under New Labour. It maintains that EM, as currently practised by the British state, is 'weak' and largely turns on the centrality of 'innovation' and 'eco-efficiency'; it then goes on to investigate in more detail the role of the market within current conceptualisations of EM and other models of green political economy. In particular, a potentially powerful distinction (both in conceptual and in policy debates) between 'the market' and 'capitalism' has yet to be sufficiently explored and exploited as a starting point for the development of radical, viable and attractive conceptions of green political economy as alternatives to both EM and the orthodox economic paradigm. In particular, the role of the market in innovation and as part of the 'governance' for sustainable development in which eco-efficiency and $\mathrm{EM}$ of the economy is linked to non-ecological demands of green politics and sustainable development, such as social and global justice, egalitarianism, democratic regulation of the market and the conceptual (and policy) expansion of the 'economy' to include social, informal and non-cash economic activity and a progressive role for the state (especially at the local/municipal level). Here, the argument is that the 'environmental' argument or basis of green political economy in terms of the need for the economy to become more resource efficient, minimise pollution and waste and so on, has largely been won. What that means is that no one is disputing the need for greater resource productivity, energy and eco-efficiency. Both state and corporate/business actors have accepted the environmental 'bottom line' (often rhetorically, but nonetheless important) as a conditioning factor in the pursuit of the economic 'bottom line'.

However, what has been less remarked upon is the social 'bottom line' and the centrality of this non-environmental set of principles and policy objectives to green political economy. In particular, the argument for lessening socioeconomic inequality and re-distributive policies to do this have not been as prominent within the green political economy and models of sustainable development as they perhaps should be. One of the 
reasons for focusing on the 'social bottom line' is to suggest that the distinctiveness and critical relevance of a distinctly 'green' (as opposed to 'environmental' or 'ecological') political economy will increasingly depend on developing a political agenda around these non-environmental/resource policy areas as states, businesses and other political parties converge around the EM agenda of reconciling the environmental and economic bottom lines, through an almost exclusive focus on the environmental bottom line. It is in developing a radical political and economic agenda around the social and economic bottom lines that the green political economy needs to focus on.

It is for this reason that the final part of the paper looks at the long-standing green commitment to re-orientate the economy towards enhancing and being judged by 'quality of life' and 'well-being'. The more recent discourse around 'economic security' is then discussed as building upon and related to the quality of life perspective, and is viewed as a potentially important driver and policy objective for green political economy in practice, in succinctly presenting the green economic case for a new type of economy, in which redistribution and reducing socioeconomic inequality are central. The model of green political economy presented here is defined in part by its commitment to 'economic security', which has the strategic political advantage of presenting a positive and attractive discourse for sustainable development arguments, unlike the (still prevalent) negative and often disempowering discourse of 'limits to growth', which does not of course mean denying the reality of limits (which are not just ecological, but also include social, cultural and psychological and biological dimensions). The point is that using the language and analysis of economic security is a more attractive and compelling way of arguing and presenting the case for a less growth-orientated economy and consumption-orientated society and one that aims for putting quality of life at the heart of economic thinking and policy.

\section{Ecological modernisation in theory and practice in Britain}

The New Labour government is clearly committed to an EM approach to sustainable development. In a speech on sustainable development Blair (2003) stated that, "tackling climate change or other environmental challenges need not limit greater economic opportunity...economic development, social justice and environmental modernisation must go hand in hand".

This 'win-win' logic has also been echoed by the deputy Prime Minister Prescott (2003), who, in a speech to the Fabian Society held that:
"There is a widespread view that environmental damage is the price we have to pay for economic progress...Modern environmentalism recognises that...an efficient, clean economy will mean more, not less economic growth and prosperity...Treating the environment with respect will not impede economic progress, it will help identify areas of inefficiency and waste and so unleash whole new forces of innovation."

Like the EM discourse, New Labour sustainable development policy rhetoric adopts the language of business and orthodox economic growth, emphasising the business case for sustainability by linking environmental management with greater resource efficiency, cost reduction and enhanced competitiveness. Typical of this is the Department for Trade and Industry, which notes that, "The environment is a business opportunity...there are 
economic benefits in reducing waste, avoiding pollution and using resources more efficiently...Reducing pollution through better technology will almost always lower costs or raise product value/differentiation" (DTI, 2000, p.7).

This business case for rendering orthodox neo-classical economic growth compatible with environmental considerations can also be found outside Westminster in the devolved administrations. In Scotland, the Scottish Executive's Enterprise Minister Jim Wallace has recently announce a 'Green Jobs Strategy', stating that:

\begin{abstract}
"Economic growth and job creation can and should go hand in hand with promoting Scotland's natural environment and, through exports, sustaining good environmental practice overseas. A Green Jobs Strategy will focus our efforts on delivering sustainable growth, which will generate employment while improving our environment and raising living standards across the country. As well as creating new business opportunities, better waste management and more efficient use of resources benefits the bottom line - raising productivity and making a big contribution to environmental targets." (Scottish Executive, 2005)
\end{abstract}

The notion that orthodox economic growth, employment and investment patterns and the cross-sectoral goals of sustainable development might be in serious tension is excluded from the government's rhetoric on the environment and the 'greening of the economy'; it is certainly not presented as a possibly problematic issue for industrial production processes or for global capitalism or the new orthodoxy of export-led growth. Instead, environmental protection and economic growth are portrayed as a positive-sum game, a 'business opportunity', suggesting that EM is the basis upon which current debates on environmental and sustainable development policy in the UK are founded (Barry and Paterson, 2004).

EM as the principle 'policy telos' (Levy and Wissenburg, 2004) for environmental and sustainable development policies within the UK (and also in other European states) stresses innovative policy tools such as market-based incentives and voluntary agreements that 'steer' businesses towards eco-efficient practices, which do not undermine 'competitiveness' and ideally should create new markets, employment, investment opportunities and technological advances. This does not rule out legislative sanctions, but EM strongly emphasises voluntary action and 'partnership' forms of environmental governance, which is in perfect keeping with not just New Labour's view of the role of the self-limiting role of state vis-a-vis the market and market actors, but also with other governments in Europe, North America and international institutions, such as the IMF and World Bank. Having established the imperative for environmental improvement with its policies, the state also plays a key role in improving the capacity of industry to respond to that imperative via, for instance, public investment in clean technology and research and development programmes and provision of information on environmental best practice, such as the recently announced 'Environment Direct' initiative containing the latest sustainable development strategy, or funded programmes in energy efficiency, such as the Energy Savings Trust, or programmes to encourage clean technology innovation, such as the Green Technology Challenge and the Sustainable Technology Initiative. Other EM initiatives include the state establishing or supporting new 'network organisations' tasked with promoting and encouraging 'win-win' environmental solutions to business, such as the Waste and Resources Action Programme (WRAP) aimed at pump priming the market for recycled materials, or other agencies charged with informing and helping businesses (especially the small and 
medium sector) in respect to environmental legislation (particularly European Union directives), or other dissemination initiatives such as the Environmental Technology Best Practice Programme and the Energy Efficiency Best Practice Programme within the DTI.

Market-based solutions have become a favoured policy tool to encourage eco-efficiency in the UK, and various environmental taxes have been introduced, such as the climate change levy, congestion charging in inner London, the landfill tax, aggregates tax and the fuel duty levy. These market-based approaches based on a voluntary and partnership approach are hallmarks of the EM portfolio of 'policy drivers' of UK sustainable development, in comparison to the more legalistic approach of other European countries, such as Germany.

One important element of such innovation is to create 'closed-loop' production, whereby waste materials are minimised and wastes themselves then become inputs to other industrial processes - central aspects of the emerging interdisciplinary science of 'industrial ecology'. The development of new markets, new commodities and services are crucial to creating the possibility of continued capital accumulation and the imperative to attract Foreign Direct Investment (FDI) while other markets are being restricted. This efficiency-oriented approach to environmental problems is central to understanding how EM is both attractive to state and business elites and managers, and some environmental NGOs.

But it is important to point out that EM processes tend to require significant state intervention. For some EM writers, there is a reliance on a notion of an 'Environmental Kuznets Curve', whereby the ecological impacts of growth go through a process where they increase, but beyond a certain point of economic output, start to decline. ${ }^{2}$ For most, this is not likely to occur, except in relation to certain measures of environmental quality, without significant state intervention to enable shifts in economic behaviour (Ekins, 2000). Thus, it is perhaps not an accident that EM discourse has arisen principally in social democratic countries in continental Europe where corporatist policy styles are still well established. EM as a 'policy ideology' has largely been developed in government programmes and policy styles and traditions, particularly those of Germany, The Netherlands, Sweden, Japan and the European Union (Weale, 1992, pp.76-85; Dryzek, 1997, pp.137-141). And while in the European countries where some of the policy outcomes associated with EM strategies, notably voluntary agreements or public-private partnerships, are often regarded as elements in a 'neo-liberalisation' of those countries, nevertheless their development still occurs within a style of policy development and implementation which is corporatist. ${ }^{3}$

Corporatist arrangements are therefore usually regarded to be the most conducive political conditions for successful environmental policy reform (e.g., Young, 2000; Dryzek, 1997; Scruggs, 1999). On this view, the state-policy elites act as brokers and prime movers in encouraging interest groups, trades unions, industry, consumer groups and sections of the environmental movement, to accept the agenda of EM. What then becomes interesting in the UK case we develop below, is the way that globalisation acts to create the potential for EM strategies in the absence of corporatist political arrangements. One argument similar to EM but couched in language more common in neo-liberal countries such as the UK and USA was popularised in an influential article by Porter and van der Linde (1995). They argue that the assumption of an economy-environment contradiction is premised on a static account of costs and fails to account for the dynamic effect that innovation has on the costs to firms of implementing 
environmental regulations. Thus policies can be pursued, which promote competitiveness for firms while reducing the environmental impacts of those firms' operations. Porter and van der Linde emphasise regulation - that state regulation can create the dynamics of technical innovation by firms, which is a 'win-win' scenario in economy-environment terms; nevertheless, the presumed relationship between states and firms is neo-liberal rather than corporatist. However, one may posit that the lack of corporatist arrangements in the UK may partly explain why EM within the UK is almost exclusively concerned with resource efficiency and technological and supply-side solutions and has little in the way of the political and social aspects of EM one can find in more corporatist states, such as Austria or Germany.

EM of course has its critics. Within EM discourse, advocates of 'strong' EM argue that its 'weak' variant is inadequate to deal with the challenge of the unsustainability of the current economic model (Dryzek, 1997, p.141). Critics of EM in general suggest that both versions are similarly problematic. In particular, the reliance on a set of technological fixes to solve what are widely seen as political problems is often perceived as a key weakness, and one of its principal limitations when compared to its sister discourse of sustainable development, which has explicit political bargains about limits and global justice built in, even in its relatively conservative versions (WCED, 1987; Langhelle, 2000). The focus on efficiency gains is often seen as wildly optimistic where all current experience suggests that in most areas, efficiency gains per unit of consumption are usually outstripped by overall increases in consumption. This is another way of saying that the notion of an Environmental Kuznets Curve, which underpins claims for the potential compatibility of growth and environmental sustainability, is implausible; drawing, as such arguments do, on a narrow set of processes and measures of environmental quality (Ekins, 2000). But EM discourse is explicit about not attempting to limit overall levels of consumption. Indeed, one of the main points of this article is to suggest that if EM is to be used as basis for developing a realistic but critical model of green political economy, EM needs to be integrated with a model of sustainable political economy in which consumption is also addressed within the context of a far more radical economic vision that focuses on economic security and quality of life, rather than orthodox economic growth, and associated policies to increase formally paid employment, attract FDI and fully integrate local and national economies into the global one. Of course whether this is possible (or desirable) is open to debate.

\section{Ecological modernisation and the UK's sustainable development strategy}

The recently launched New Labour's sustainable development strategy, Securing the Future: Delivering the UK Sustainable Development Strategy (DEFRA, 2005), a follow-up to the 1999 strategy document, A Better Quality of Life (DEFRA, 1999) is a timely publication to take stock and assess the role of EM within official government thinking on the transition to the a more sustainable economy and society.

Of particular interest is Chapter 3 of the Strategy, 'One planet economy: sustainable production and consumption'. While containing some positive features, not least the over-arching idea of living within a sustainable 'ecological footprint'; greater support for ecological innovation and resource productive technologies; enabling us to 'achieve more with less' and in relation to the key but challenging issue of consumption, the report 
while woefully inadequate, does at least place the issue of tackling and adddressing consumption alongside the more long-standing productive focus of UK sustainable development strategy. The strategy document studiously avoids what many would see as the real issue with consumption - i.e., how to reduce it rather than simply focus on making it 'greener' or lessen its environmental impact. The report notes that:

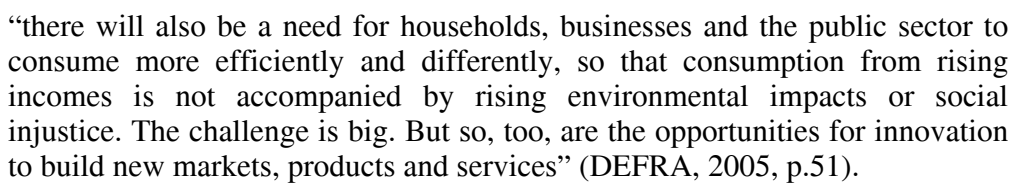

At no point in the report is the question of reducing or maintaining consumption discussed, or relating consumption and patterns of consumption to quality of life or well-being.

The extent of government action or policy in respect to consumption amounts to a series of 'processes' such as:

1 "building an evidence base around the environmental impacts arising from households and how patterns of use can be influenced

2 working on a new information service - 'Environment Direct'...

3 through a refocused Environmental Action Fund...

4 delivering a large-scale deliberative forum to explore public views on sustainable consumption and lifestyles...

5 the new Round Table on Sustainable Consumption” (DEFRA, 2005, p.52).

Of these, perhaps most hope lies in the deliberative forum and the Round Table in raising the central but complex and difficult issue of reducing consumption and not simply changing current patterns of consumption per se, which leaves the quantity of consumption unchanged or premised on increasing consumption. Before going on to look at the way in which the document articulates an EM view, it is worth looking briefly at the role of consumption both within EM as the dominant view of sustainable development within government thinking.

One of the limitations with EM, as many authors and critics have pointed out (Barry, 2003a), is its focus on the production side of economic activity and its impact on the environment - leading to its main focus on finding ways of increasing resource efficiency. What is missing from the EM agenda is a concern with sustainable consumption to balance with sustainable production patterns and technologies. Indeed, I would suggest that the integration of serious consideration as to how to tackle consumption into the EM framework holds out the possibility of a positive and more robust model of green political economy, which is more consistent with basic green political and normative goals (particularly, as indicated in the concluding sections of this paper, EM can be framed within an overarching policy approach to sustainable development aimed at producing 'economic security' and 'well-being' rather than orthodox 'economic growth'). 
The thinking behind Jackson's (2005) recent report for the Sustainable Development Research Network entitled Motivating Sustainable Consumption seems to have influenced the strategy's focus on providing deliberative fora and government leading by example in terms of public procurement, as the main policy contribution towards addressing sustainable consumption.

The conclusions of his report are as follows:

\begin{abstract}
"Changing behaviour is difficult. The evidence in this review is unequivocal in that respect. Overcoming problems of consumer lock-in, unfreezing old habits and forming new ones, understanding the complexity of the social logic in which individual behaviours are embedded: all these are prerequisites for successful behaviour change initiatives. But in spite of all appearances, this complex terrain is not intractable to policy intervention. Policy already intervenes in human behaviour both directly and indirectly in numerous ways...a genuine understanding of the social and institutional context of consumer action opens out a much more creative vista for policy innovation than has hitherto been recognised. Expanding on these opportunities is the new challenge for sustainable consumption policy.

In following up on these possibilities, Government can draw some clear guidance from the evidence base. In the first place, leading by example is paramount. The evidence suggests that discursive, elaborative processes are a vital element in behaviour change - in particular in negotiating new social norms and 'unfreezing' habitual behaviours. This shift from 'deliberation' to 'elaboration' as a working model of behavioural change can be seen as a key message of this study.” (Jackson, 2005, pp.132-133)
\end{abstract}

Jackson goes on to point out that there is perhaps some hope to be found in more participatory community-based approaches to changing patterns of consumption. According to him:
"In particular, the relevance of facilitating conditions, the role of lock-in and the critical importance of the social and cultural context emerge as key features of the debate. The role of community in mediating and moderating individual behaviours is also clear. There are some strong suggestions that participatory community-based processes could offer effective avenues for exploring pro-environmental and pro-social behavioural change. There are even some examples of such initiatives, which appear to have some success. What is missing from this evidence base, at present, is unequivocal proof that community-based initiatives can achieve the level of behavioural change necessary to meet environmental and social objectives." (Jackson, 2005, p.133)

This does seem to suggest that there is a role not just for deliberative, community-based processes (as indicated in the DEFRA strategy document) as enabling processes to overcome the obstacles to more sustainable patterns of consumption, but also of the possible role of community-based initiatives for delivering sustainable consumption itself. Here, the role of the social economy and community-based enterprises can be seen as important loci for sustainable consumption, as well as sustainable production, suggesting a happy marriage between the three bottom lines of sustainable development within this sector (Barry and Smith, 2005). ${ }^{4}$ 
Jackson concludes that:

\begin{abstract}
"It is clear from this that behaviour change initiatives are going to encounter considerable resistance unless and until it is possible to substitute for these important functions of society in some other ways. In this context, motivating sustainable consumption has to be as much about building supportive communities, promoting inclusive societies, providing meaningful work, and encouraging purposeful lives as it is about awareness raising, fiscal policy and persuasion. This is not to suggest that Government should be faint-hearted in encouraging and supporting pro-environmental behaviour. On the contrary, a robust effort is clearly needed; and the evidence reviewed in this study offers a far more creative vista for policy innovation than has hitherto been recognised." (Jackson, 2005, pp.133-134).
\end{abstract}

Whether or not the British state's existing EM approach to sustainable development (with its focus on resource efficiency and greening production within a conventional economic model which seeks to promote economic growth and competitiveness) can be integrated with a focus on sustainable consumption remains to be seen, and the current DEFRA sustainable development strategy can be seen as indicating some tentative steps in that direction. However, I suggest that the government's approach to sustainable consumption as a whole will probably be a version of its approach to private car transport - encouraging people to buy (and manufacturers to produce) more fuel-efficient and more ecologically responsibly produced cars, while doing little to regulate their use or provide attractive public transport alternatives to reduce their overuse (Barry and Paterson, 2004).

The judgement of environmental groups, such as Friends of the Earth (FoE), is that the New Labour government has produced 'more green smoke than the Wizard of Oz'. Friends of the Earth, in a press statement in December 2002 claimed that:

\begin{abstract}
"Despite promising to cut traffic levels in 1997, the Government has done precious little to achieve this. The cost of motoring has fallen under Labour, whilst the cost of using buses and trains has risen. The Government abandoned the fuel price escalator following protests from motoring groups. Labour has offered only lukewarm support to the few local authorities that have introduced congestion-charging. Billions of pounds of road-widening schemes were announced last week - even though the Government stated in its 1998 Transport White Paper 'people know we cannot build our way out of congestion with new roads.' The Government has admitted that road congestion is unlikely to improve by the end of the decade. Since Labour came to power in 1997, road traffic is estimated to have grown by $7 \%$. There has been inadequate funding for transport alternatives to the car." (FoE, 2002)
\end{abstract}

A clear indication of the EM approach adopted in the DEFRA report is the linking of economic competitiveness, innovation and the environment, building on the Government's previous 2003 Innovation review, which identified the environment as a key driver of innovation (DEFRA, 2005, p.44). This focus on innovation, resource efficiency and so on, should be welcomed and is a key part of the EM agenda in general, and the ecologically modernising state in particular (Barry, 2003a).

A central aspect of the state in EM is its 'enabling', coordinating and supporting role, in terms of encouraging technological innovation and greater economic and ecologically efficient use of resources and energy. Through subsidies and research and development assistance for renewable energy, or investment in fuel cell technology, to forms of environmental regulation, setting emissions standards, environmental taxes and other regulatory mechanisms: "Regulation can be used to drive the process of industrial 
innovation with environmental and economic gains realised as a result" (Murphy and Gouldson, 2000, p.43). Indeed, much of the 'modernisation' aspect of EM rests on the central emphasis on innovation, both technologically as well as in production processes and management and distribution systems. ${ }^{5}$ Smart production systems, 'doing more with less', applying novel scientific breakthroughs (for example in renewable energy, biotechnology and information and communication technology, such as nanotechnology) and developing and utilising 'clean' technologies, are all hallmarks of the modern, dynamic, forward-looking, solutions-focused character of EM. While the state 'enables' and supports innovation, it is left to the private sector to develop, test and market these new ecologically efficient innovations and production methods.

However, while the issue of consumption is not (yet) integrated within EM thinking, a related and perhaps more damning critique from a robust or radical conception of sustainable development, is that EM is explicitly viewed as contributing to, rather than challenging or changing the orthodox economic policy objective of growth in the formal economy as measured by GNP/GDP. In short, EM - at most - deals with the effects rather than the underlying causes of unsustainable development.

\section{From economic growth to economic security}

Indeed, I would suggest that any plausibly 'green' and radical conception of political economy must be articulated. That is, for a model of political economy to be classed as 'green', this critique of conventional, neo-classical economic growth as the main economic policy objective of any state or society is a sine qua non. Now, while there are many debates as to the different understandings and measurements of 'economic growth' (does growth refer to increases in monetary value or does it refer to physical/resource measures?), a 'post-growth' economy is one that has featured prominently within green political and economic discourse, most usually associated with the environmental benefits of a less growth-orientated and programmed economic system.

A major report by the International Labour Organisation (ILO, 2004) Economic Security for a Better World found that economic security coupled with democracy and equality were key determinants of well-being and social stability. According to this report:
"People in countries that provide citizens with a high level of economic security have a higher level of happiness on average, as measured by surveys of national levels of life-satisfaction and happiness...The most important determinant of national happiness is not income level - there is a positive association, but rising income seems to have little effect as wealthy countries grow wealthier. Rather the key factor is the extent of income security, measured in terms of income protection and a low degree of income inequality." (ILO, 2004)

Such findings give empirical support to long-standing green arguments stressing the need for policies to increase well-being and quality of life, rather than conventionally measured economic growth, rising personal income levels or orthodox measures of wealth and prosperity. 
In particular, the report confirms the long-standing green critique of economic growth as necessarily contributing to well-being. It states that:

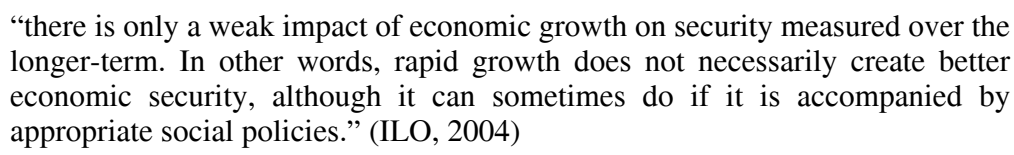

Of particular note is that many of the policies the ILO recommends to accompany an orthodox growth objective go against the neo-liberal/Washington consensus model - premised on increasing the openness of national economies to one another, integrating them into the global market and prioritising trade and FDI as the main determinants of domestic economic growth. The ILO report makes the point that:
"For developing countries, the national level of economic security is inversely related to capital account openness, implying that it would be sensible for developing countries to delay opening their capital accounts until institutional developments and social policies were in place to enable their societies to withstand external shocks. In other words, countries should postpone opening their financial markets until they have the institutional capacities to handle fluctuations in confidence and the impact of external economic developments." (ILO, 2004)

That a democratic political system has no necessary connection with ever increasing levels of material consumption is a touchstone of green democratic arguments (Barry, 1999), and indeed democratic and egalitarian principles are at the heart of sustainable development (Jacobs, 1999). More important to a democratic polity is a well-developed 'democratic culture', a shared sense of citizenship, plurality and socioeconomic and political equality. Plurality and equality are more significant than prosperity as preconditions for an ongoing and vibrant democracy. In other words, a shift away from 'economic growth' and orthodox understandings of 'prosperity' should be taken as an opportunity by the green theory to redefine basic political and economic concepts. It asks us to consider the possibility that human freedom and a well-organised and governed polity does not depend, in any fundamental sense, on increasing levels of material affluence. Indeed, there may be a trade-off between democracy and orthodox economic growth and a related government policy heavily or exclusively focused on improving material well-being.

According to a study by Lauber (1978) in the late 1970s, there is evidence to show that the relatively democratic and liberal, and consequently less powerful, British state has been an important determinant of the stagnation and decline of its economy since the second world war. Relying on the comparative studies of Schonfield (1965), he states that:

\footnotetext{
"the governments that have been most successful in the pursuit of the new [economic] goals have been those which had few doubts about the extensive use of non-elected authority, for example, France. The more 'timid' governments were less successful." (Lauber, 1978, p.209)
}

Having 'modernisation' and the pursuit of orthodox economic growth as one's highest goal can lead to non-democratic, illiberal forms of state action, or policies and styles of governance that at the very least are at odds with a pluralist and liberal democratic system. 
It needs to be recalled that the 'free market' revolution ushered in by the likes of Thatcher in the UK and Reagan in the USA were also accompanied by a centralisation and strengthening of the state, and a redrawing of the relationship between state and civil society, which privileged the former over the latter. The 'free market and strong state' are both still with us, increasingly integrated under economic globalisation and those governments - such as New Labour - that embrace and promote a broadly neoliberal version of globalisation (Barry and Paterson, 2004).

The ILO report quoted earlier provides other evidence of the dangers of economic growth policies that undermine economic (and communal) security. The report finds that:

\begin{abstract}
"the global distribution of economic security does not correspond to the global distribution of income, and that countries in South and Southeast Asia have a greater share of global economic security than their share of the world's income... By contrast, Latin American countries provide their citizens with less economic security than could be expected from their relative income levels. Indeed, being insecure has resonance in people's attitudes, which at times can be detrimental to their ideas of a decent society. In a recent survey taken by the Latino barometro in Latin America, $76 \%$ of the people surveyed were concerned about not having a job the following year, and a majority said that they would not mind a non-democratic government if it could solve their unemployment problems." (ILO, 2004)
\end{abstract}

So, not only states, but citizens can contemplate and act in non-democratic ways in pursuit of orthodox economic modernisation and economic growth objectives. If one values democracy and its values of pluralism, freedom, equality and so on, then one has to seriously question any putative or enforced connection between its maintenance and further development and orthodox policies aimed at economic growth. ${ }^{6}$ The ILO report goes on to note that "economic insecurity fosters intolerance and stress, which contribute to social illness and ultimately may lead to social violence" (ILO, 2004). ${ }^{7}$

Beyond a certain threshold, greater increases in the latter may be accompanied by decreases in the former. An economy less geared towards universalising and promoting materially affluent lifestyles and consumption may be consistent with enhanced democratic practice since the decrease in complexity, social division of labour, inequality and hierarchy, allows the possibility of greater participation by individuals in the decisions that affect their lives and that of their communities. For example, a shift away from economic growth as a central social goal would undermine the justification of socioeconomic inequalities on the grounds that they are necessary 'incentives' to achieve economic growth. At the same time, as early proponents of the steady-state economy pointed out, the shift from a society geared towards economic growth, to a society where material growth is not a priority may lead to more extensive re-distributive measures, a point made many years ago by forerunners of green economic thinking, such as Daly (1973). This re-distributive aspect to the sustainability critique of excessive material development echoes the socialist critique of the disparity between formal political equality and socioeconomic inequality within capitalism. Indeed, the findings of the ILO report not only strengthen sustainability arguments concerning the non-democratic and non-well-being contribution of economic growth policies, but also point out the dangers of authoritarian positions. 
Over 150 years ago, de Tocqueville (1956, pp.129-130) suggested that:
"General prosperity is favourable to the stability of all governments, but more particularly of a democratic one, which depends upon the will of the majority, and especially upon the will of that portion of the community that is most exposed to want. When the people rule, they must be rendered happy or they will overturn the state: and misery stimulates them to those excesses to which ambition rouses kings."

This assumption of the positive correlation between material affluence and the stability of a democratic political order is one which is closely associated with 'modern' political traditions such as liberalism and Marxism. ${ }^{8}$ In this section it is the negative corollary of this assumption, i.e., that material scarcity creates the conditions for political instability and a shift to authoritarianism that will be examined. What can be called a 'Hobbes-Malthus' position underpins the 'eco-authoritarian' school of green thought (Barry, 1999), which in the literature is most closely associated with Ophuls (1977), Hardin $(1968 ; 1977)$ and Heilbroner (1980). The eco-authoritarian implication of the link between scarcity and political arrangements has been forcefully made by Ophuls (1977, p.8). He begins from the assumption that:

\begin{abstract}
"The institution of government, whether it takes the form of primitive taboo or parliamentary democracy...has its origins in the necessity to distribute scarce resources in an orderly fashion. It follows that assumptions about scarcity are absolutely central to any economic or political doctrine and that the relative scarcity or abundance of goods has a substantial and direct impact on the character of political, social and economic institutions."
\end{abstract}

Calling the affluence experienced by western societies over the last 200 years or so 'abnormal', a material condition that has grounded individual liberty, democracy and stability (Ophuls, 1977, p.12), he concludes that with the advent of the ecological crisis, interpreted as a return to scarcity (following 'the limits to growth' thesis), 'the golden age of individualism, liberty and democracy is all but over. In many important respects we shall be obliged to return to something resembling the pre-modern closed polity' (Ophuls, 1977, p.145).

These eco-authoritarian arguments can be countered if one focuses not on economic prosperity or growth as the main connection between democracy and individual freedom and social and political stability, but on economic security. In part, what this implies is that economic growth policies to be effective in promoting the goal of economic security need to be connected to re-distributive and other policies. Particularly, in addition to supporting policies promoting job security (and job/skill satisfaction), ${ }^{9}$ and those promoting income security within employment (such as minimum wage legislation), greens have also been long-standing advocates for income security outside the formal employment sphere, through a universal, rights-based provision of a basic citizen's income; they also promote the basic claim that 'work' (socially useful, necessary but often in the non-monetised and informal economy) should not be either conflated with, nor deemed to be less socially valued than formally paid employment. ${ }^{10}$ 


\section{Conclusion: Integrating ccological modernisation, innovation and economic security?}

Viewed by itself, EM is a reformist and limited strategy for achieving a more sustainable economy and society, and indeed, questions could be legitimately asked as to whether the development of a recognisably 'green' political economy for sustainable development can be based on it, I nevertheless contend that there are strategic advantages in seeking to build upon and radicalise EM. While there are various reasons one can give for this, in this conclusion I will focus on two - one normative/principled, the other strategic.

From a strategic point of view, it is clear that, as Dryzek et al. (2003) have shown, if green and sustainability goals, aims and objectives are to be integrated within state policy, these need to attach themselves to one of the core state imperatives - accumulation/economic growth or legitimacy (Barry, 2003b). It is clear that the discourse on EM allows (some) green objectives to be integrated/translated into a policy language and framework which complements and does not undermine the state's core imperative of pursuing orthodox economic growth. Therefore, in the absence of a Green Party forming a government or being part of a ruling coalition (or even more unlikely, of one of the main traditional parties initiating policies consistent with a radical understanding of sustainable development), the best that can be hoped for under current political conditions is the 'greening of growth and capitalism' i.e., EM.

On a more principled note, the adoption of EM as a starting point for the development of a model/theory of green political economy does carry with it the not inconsiderable benefit of removing the 'anti-growth' and 'limits to growth' legacy, which has (in my view) held back the theoretical development of a positive, attractive, modern conceptualisation of green political economy and radical conceptualisations of sustainable development. Here, the technological innovation, the role of regulation driving innovation and efficiency, the promise that the transition to a more sustainable economy and society do not necessarily mean completely abandoning currently lifestyles and aspirations - strategically important in generating democratic support for sustainable development, and as indicated above, important if the vision of a green sustainable economy is one that promotes diversity and tolerance in lifestyles and does not demand everyone conform to a putative 'green' lifestyle. Equally, this approach does not completely reject the positive role/s of a regulated market within sustainable development. However, it does demand a clear shift towards making the promotion of economic security (and quality of life) central to economic policy. Only when this happens can we say that we have begun the transition to implementing the principles of sustainable development rather than fruitlessly seeking for some 'greenprint' of an abstract and utopian vision of the 'sustainable society'. 


\section{References}

Allison, L. (1991) Ecology and Utility: The Philosophical Dilemmas of Planetary Management, Leicester: Leicester University Press.

Barry, J. (1999) Rethinking Green Politics: Nature, Virtue and Progress, London: Sage.

Barry, J. (2001) 'Greening liberal democracy: theory, practice and political economy', in J. Barry and M. Wissenburg (Eds.) Sustaining Liberal Democracy, London: Palgrave.

Barry, J. (2003a) 'Ecological modernisation', in E. Page and J. Proops (Eds.) Environmental Thought, London: Edward Elgar.

Barry, J. (2003b) 'Holding tender views in tough ways: political economy and strategies of resistance in green politics', British Journal of Politics and International Relations, Vol. 5, No. 4.

Barry, J. and Paterson, M. (2004) 'Globalisation, ecological modernisation, and new labour', Political Studies, Vol. 4, p.54.

Barry, J. and Smith, G. (2005) 'Green political economy and the promise of the social economy', in P. Dauvergne (Ed.) International Handbook of Environmental Politics, Cheltenham: Edward Elgar.

Barry, J. and Wissenburg, M. (Eds.) (2001) Sustaining Liberal Democracy, London: Palgrave.

Bell, D. (2002) 'How can political liberals be environmentalists?', Political Studies, Vol. 50, No. 4, pp.703-724.

Blair, T. (2003) Sustainable Development Helps the Poorest, http://www.labour.org.uk/tbsd/ (accessed 13 June 2005).

Cole, M. (2000) Trade Liberalisation, Economic Growth and the Environment, Cheltenham: Edward Elgar.

Copp, D., et al. (1995) 'Introduction', in D. Copp, J. Hampton and J. Roemer (Eds.) The Idea of Democracy, Cambridge: Cambridge University Press.

Daly, H. (Ed.) (1973) Toward a Steady State Economy, San Francisco: Freeman.

Department of Environment, Food and Rural Affairs (DEFRA) (1999) A Better Quality of Life, London: HMSO.

Department of Environment, Food and Rural Affairs (DEFRA) (2005) Securing the Future: Delivering the United Kingdom Sustainable Development Strategy, London: HMSO.

Department of Trade and Industry (DTI) (2000) Sustainable Development Strategy, www.dti.gov.uk/sustainability/strategy/ (accessed 1 June 2005).

Dryzek, J. (1997) The Politics of the Earth, Oxford: Oxford University Press.

Dryzek, J., Downes, D., Hunold, C., Schlosberg, D. and Hernes, H.K. (2003) Green States and Social Movements, Oxford: Oxford University Press.

Eckersley, R. (1992) Environmentalism and Political Theory: Toward an Ecocentric Approach, London: University of London Press.

Ekins, P. (2000) Economic Growth and Environmental Sustainability: The Prospects for Green Growth, London: Routledge.

Friends of the Earth (FoE) (2002) Government Failing to Tackle Transport Crisis, http://www.foe.co.uk/pubsinfo/infoteam/pressrel/2002/20021217170949.html (accessed 8 January 2003).

Goodin, R. (1992) Green Political Theory, Oxford: Oxford University Press.

Hailwood, S. (2004) How to be a Green Liberal: Nature, Value and Liberal Philosophy, Chesem: Acumen.

Hardin, G. (1968) 'The tragedy of the commons', Science, p.168.

Hardin, G. (1977) The Limits to Altruism, Indianapolis: Indiana University Press.

Harvey, D. (1996) Justice, Nature and the Geography of Difference, Oxford: Blackwell. 
Hayward, T. (1995) Ecological Thought: An Introduction, Cambridge: Polity.

Heilbroner, R. (1980) An Inquiry into the Human Prospect, 2nd ed., New York: W.W. Norton.

International Labor Organisation (2004) Economic Security for a Better World, Geneva: ILO.

Jackson, T. (2005) Motivating Sustainable Consumption, London: Sustainable Development Research Network.

Jacobs, M. (1999) 'Sustainable development as a contested concept', in A. Dobson (Ed.) Fairness and Futurity, Oxford: Oxford University Press.

Korten, D. (1995) 'Civic engagement to create just and sustainable societies for the 21st century', Paper Prepared for the Habitat II Conference.

Langhelle, O. (2000) 'Why ecological modernisation and sustainable development should not be conflated', Journal of Environmental Policy and Planning, Vol. 2, No. 4, pp.303-322.

Lauber, V. (1978) 'Ecology, politics and liberal democracy', Government and Opposition, Vol.13, No.2.

Levy, Y. and Wissenburg, M. (2004) 'Sustainable development as a policy telos: a new approach to political problem-solving', Political Studies, Vol. 4, p.54.

Lukes, S. (1984) 'Marxism and utopianism', in P. Alexander and R. Gill (Eds.) Utopias, London: Duckworth.

McMurtry, J. (1996) The Cancer Stage of Capitalism, London: Pluto Press.

Mayo, E. and Moore, H. (2001) The Mutual State: How Local Communities can Run Public Services, London: New Economics Foundation.

Murphy, J. (2001) 'Ecological modernisation: the environment and the transformation of society', OCEES Research Paper, Oxford, No. 20.

Murphy, J. and Gouldson, A. (2000) 'Environmental policy and industrial innovation: integrating environment and economy through ecological modernisation', Geoforum, Vol. 31, p.1.

Ophuls, W. (1977) Ecology and the Politics of Scarcity, San Francisco: Freeman.

Porter, $M$ and van der Linde, C. (1995) 'Toward a new conception of the environment-competitiveness relationship', Journal of Economic Perspectives, Vol. 9, No. 4, pp.97-118.

Prescott, J. (2003) 'Environmental modernisation', Speech to Fabian Society/SERA Conference.

Schonfield, A. (1965) Modern Capitalism, Oxford: Oxford University Press.

Scottish Executive (2005) Proposals for Green Jobs Strategy, http://www.scotland.gov.uk/News/ Releases/2004/06/5656 (accessed 26 June 2005).

Scruggs, L. (1999) 'Institutions and environmental performance in seventeen democracies', British Journal of Political Science, Vol. 29, No. 1, pp.1-31.

Sklair, L. (2001) The Transnational Capitalist Class, Oxford: Blackwell.

de Tocqueville, A. (1956) Democracy in America, in R. Heffner (Ed.), New York: Mentor Books.

Weale, A. (1992) The New Politics of Pollution, Manchester: Manchester University Press.

Wissenburg, M. (1998) The Free and the Green Society: Green Liberalism, London: University College London Press.

World Commission on Environment and Development (1987) Our Common Future, Oxford: Oxford University Press.

Young, S. (Ed.) (2000) The Emergence of Ecological Modernisation: Integrating the Environment and the Economy?, London: Routledge. 


\section{Bibliography}

Daly, H. (1985) 'Economics and sustainability: in defense of a steady-state economy', in M. Tobias (Ed.) Deep Ecology, San Diego: Avant.

Department of Environment, Transport and the Regions (1999) A Better Quality of Life: A Strategy for Sustainable Development for the UK, London: HMSO.

Dobson, A. (1995) Green Political Thought, 2nd ed., London: Routledge.

Dryzek, J. (1996) 'Foundations for environmental political economy: the search for homo ecologicus', New Political Economy, Vol. 1, No. 1, pp.27-40.

International Labour Organisation (ILO) (2005) Security for a Better World, http://www.ilo.org/ public/english/protection/ses/index.htm (accessed 10 October 2004).

\section{Notes}

1 On the relationship between 'liberalism' (and liberal democracy) and green politics and sustainability, see Eckersley (1992), Barry and Wissenburg (2001), Hailwood (2004), Wissenburg (1998) and Bell (2002).

2 The 'Environmental Kuznets Curve' (EKC) approach is the principal site where an attempt is made to demonstrate (rather than assert) the potential to combine environmental improvements with economic growth (Ekins, 2000; Cole, 2000). The basic assumption of the EKC analysis is that continued economic growth passes a point beyond which environmental degradation begins to decrease (Ekins, 2000, pp.182-183).

3 By 'neo-liberalism' I mean the ideology which promotes the deregulation of markets, the rolling back of the state, and the progressive dismantling or 'hollowing out' of the welfare state, the opening of domestic markets to the world economy and the creation of the 'competition state' (Sklair, 2001). By corporatism, I mean institutionalised regimes and procedures within a society whereby the elites and representatives of the state/government of the day, dominant market interests and actors and organised labour together 'corporately' set the framework of public policy.

4 Indeed, the role of the social economy within any realistic but radical conception of green political economy is something that needs to be recognised and deserves more space that I can give it here. For further analysis of the potential role of the social economy and social enterprises as a central aspect of a sustainable economy see Korten (1995) and Mayo and Moore (2001) as well the work of the New Economics Foundation.

5 'Innovation is central to ecological modernisation of production because it is through innovation and change that environmental concerns can begin to be integrated into production' (Murphy, 2001, p.9).

6 At this point the 'liberal/post-liberal' character of the model of green political economy outlined here needs to be again stressed, particularly in the way that, as I have argued elsewhere (Barry, 2001), this green, post-liberal model of green political economy requires a separation of (a) liberalism from capitalism and (b) the separation of democracy from currently liberal democratic forms.

7 A full analysis here would involve examination of the ways in which the privatising of the commons and the undermining of welfare state provided public services and goods, fosters economic security as a necessary not a contingent aspect of 'modernisation' and 'restructuring', such as Structural Adjustment Programmes. A provocative account of the link between the erosion of public welfare provision and socio-economic insecurity and inequality as well as ecological unsustainability is the work of McMurtry (1996). According to him, "the inner logic of the global market system is not to solve debt crisis, but to keep governments indebted on a permanent and rising basis, while continuing to selectively feed on and dismantle social sectors" (1996, p.78). He goes on to point out that, "Everywhere market 'restructurings' and 'adjustments' have escalated social inequalities, consistently increased 
real unemployment rates and part-time jobs without benefits, eliminated or reduced minimum wages, and reduced the lifelines of funding to every public form of social security, learning, health-care, culture, and transportation which societies have achieved over half a century or more of social development" (McMurtry, 1996, p.148).

8 Classical liberals such as Tocqueville assumed a relationship between an affluent economy and political democracy. One aspect of Tocqueville's thought turns on the idea that "a flourishing economy is essential to the stability of democracy, since it gives defeated politicians an alternative, which makes them more likely to accept defeat rather than attempt to illegally to hold on to office" (Copp et al., 1995, p.3). Classical Marxism, on the other hand, assumed a connection between 'emancipation' and material abundance. The roots of the different understandings of the connection between the two may lie in the inter-relationship between the logics and legacies of the Industrial and French Revolutions, understood as expressing the core values of modernity, one relating to economic abundance and the other to political democracy.

9 Another of the ILO report's findings was that one of the seven forms of work-related security, skills security was "inversely related to well-being when jobs are poorly attuned to the needs and aspirations of people, especially as they become more educated and acquire more skills and competencies. At present, too many people are finding that their skills and qualifications do not correspond to the jobs they have to perform, resulting in a 'status frustration' effect" (ILO, 2004). One of the clear implications of this is that the mantra that job creation per se is all that matters is one that does not necessarily support economic security and the promotion of well-being. From a purely economistic and orthodox position promoting economic growth, employment creation is completely indifferent to the quality or the types of jobs that are being created. On this orthodox economic view, short-term, low-paid, low-skilled jobs ('McJobs' or jobs in call-centres for example) are to be judged as the same as skilled, highly-paid jobs with high levels of job satisfaction and job security.

10 In this way it is clear that the model of green political economy outlined here necessarily goes beyond the conventional understanding of the 'economy' and moves in the direction of an expansive view of the economy which includes the unpaid gendered caring work of women and others, and non-market contributors to human well-being and quality of life. 